\title{
ANALISIS PENGARUH PENERAPAN IFRS MENGENAI INVESTMENT PROPERTY TERHADAP PENYAJIAN LAPORAN KEUANGAN (STUDI KASUS PADA PERUSAHAAN SEKTOR OTOMOTIF YANG TERDAFTAR DI BEI)
}

\author{
Hendro Sasongko \\ Dosen Tetap Fakultas Ekonomi \\ Universitas Pakuan \\ Dida Marhamah \\ Mahasiswa Fakultas Ekonomi \\ Universitas Pakuan
}

\begin{abstract}
ABSTRAK
Properti investasi merupakan salah satu akun yang muncul dalam kelompok aset tidak lancar pada laporan posisi keuangan perusahaan. Penyajian tiap akun dalam laporan keuangan tentu harus didasarkan pada PSAK yang berlaku dan diberlakukan oleh IAI. Penerapan PSAK tentu akan berpengaruh terhadap kewajaran penyajian laporan keuangan yang pada umumnya dicerminkan oleh opini auditor independen atas laporan keuangan. Adanya revisi PSAK 13 sebagai adopssi IFRS mengenai Investment Property dianggap akan mempengaruhi penyajian laporan keuangan perusahaan sektor otomotif yang terdaftar di BEI.

Metode penelitian yang digunakan adalah metode deskriptif dengan pendekatan deduktif serta studi kasus pada delapan perusahaan sektor otomotif di BEI. Dari hasil penelitian yang dilakukan, diperoleh hasil bahwa telah terjadi revisi atas PSAK 13 yakni di tahun 2007 dan terakhir di tahun 2011, mengadopsi IAS 40 dalam IFRS. Perubahan atas PSAK tersebut telah diaplikasikan oleh seluruh perusahaan sampel. Tiga dari delapan perusahaan sampel mengubah model pengukuran atas properti investasi dari model biaya menjadi model nilai wajar sebagaimana diperkenankan dalam PSAK 13 revisi 2007 maupun 2011. Selain pengukuran akuntansinya, perolehan, pengungkapan, dan penyajian atas properti investasi kedelapan perusahaan sampel juga telah merepresentasikan perlakuan akuntansi atas properti investasi PSAK 13 yang telah direvisi.
\end{abstract}

Kata kunci: Investment Property dan Laporan Keuangan

\section{Pendahuluan}

Dalam pelaporan keuangan perlu adanya pedoman atau standar yang menetapkan bentuk formal serta material atas laporan keuangan perusahaan guna memberikan interpretasi 
yang baik bagi para pengguna laporan keuangan. Standar akuntansi diterima secara umum sebagai aturan baku yang didukung oleh sanksi-sanksi untuk setiap ketidak patuhan (Belakoui, 2006 dalam Chariri dan kusuma, 2010). Dengan adanya standar dalam pennyajian laporan keuangan, diharapkan kebutuhan informasi akuntansi dan keuangan para user dapat terpenuhi. Selain itu, pengguna standar menjadikan laporan keuangan dapat diperbandingkan baik secara vertikal (atar perusahaan sebidang) maupun horizontal (antar periode). Di Indonesia, lembaga yang berwenang untuk mengatur dan menetapkan standar laporan keuangan dikenal dengan IAI (Ikatan Akuntan Indonesia) dengan PSAK (Pernyataan Standar Akuntansi Keuangan) yang dijadikan sebagai pedoman penyusunan laporan keuangan perusahaan terutama perusahaan dengan akuntabilitas publik.

Adanya PSAK yang diperuntukan bagi perusahaan dengan akuntabilitas di negeri ini belum banyak memberikan manfaat bagi para investor asing. Sedangkan di era globalisasi ini, investor tidak hanya dari lingkup nasional saja, banyak pula investor asing yang tertarik untuk menanamkan modalnya di Indonesia. Globalisasi menuntut adanya harmonisasi standar dalam laporan keuangan. Harmonisasi standar tersebut dibuat guna menghilangkan hambatan arus modal internasional dengan meminimalisir perbedaan-perbedaan dalam sistem akuntansi dan ketentuan pelaporan keuangan. Kualitas standar akuntansi sangat berperan dalam pengembangan kualitas struktur pelaporan keuangan global. Standar akuntansi yang berkualitas meliputi prinsip-prinsip komprehensif yang netral, konsisten, sebanding, relevan, dapat diandalkan dan berguna bagi investor, kreditor dan pihak lain untuk membuat keputusan alokasi modal (Roberts et. al. Dalam Situmorang, 2011). Oleh karena itu IAI mengkorvergensikan PSAK ke IFRS untuk kepentingan global.

Penerapan IFRS akan mempengaruhi berbagai aspek dalam perusahaan, terutama aspek pelaporan intern dan basis penelitian. Tsalavoutas dan Evan (2010) mengungkapkan bahwa adopsi IFRS berpengaruh signifikan terhadap shareholder equity, net income, dan liquidity. Penggunaan nilai wajar yang diadopsi dari IFRS salah satunya adalah penggunaan dalam penilaian properti investasi yang diatur dalam PSAK 13. Dalam PSAK setelah adopsi IFRS, pengukuran properti inestasi diperbolehkan memilih salah satu dari dua alternatif pengukuran properti investasi yang harus diterapkan dengan konsistensi oleh setiap perusahaan. Alternatif pengukuran yang dimaksud adalah model biaya dan model nilai wajar. Penggunaan nilai wajar dipandang mampu menyediakan informasi yang lebih relevan dalam pengambilan keputusan. 
Penggunaan nilai wajar dalam pengukuran properti investasi akan menimbulkan perubahan nilai properti investasi tersebut. perubahan nilai yang dimaksud dapat berupa dua kemungkinan yakni perubahan berupa kenaikan nilai atau justru penurunan nilai atas properti investasi tersebut. ketika properti investasi mengalami kenaikan maka keuntungan didapatkan perusahaan dari adanya selisih nilai tersebut dan jika nilai properti investasi mengalami penurunan maka kerugianlah yang harus ditanggung perusahaan. Sehingga penggunaan model nilai wajar tentu akan berpengaruh terhadap pengakuan laba perusahaan.

Tujuan penelitian ini yaitu untuk menganalisis penerapan IFRS mengenai Investment Property pada perusahaan subsektor otomotif yang terdaftar di BEI, menganalisis penyajian laporan keuangan perusahaan subsektor otomotif yang terdaftar di BEI, menganalisi pengaruh penerapan IFRS mengenai investment property terhadap penyajian laporan keuangan perusahaan subsektor otomotif yang terdaftar di BEI.

\section{Metode Penelitian}

Penelitian dilakukan dengan melakukan analisis atas pelaporan properti investasi seluruh sample guna mendapatkan pemahaman atas praktik penyajian dan pengungkapan properti investasi dalam laporan keuangan perusahaan.

Analisis dilakukan dengan langkah awal memilah laporan keuangan auditan perusahaan beserta opini yang diperoleh atas laporan keuangan tiap perusahaan. Kemudian, menelusuri penggunaan PSAK di dalam penyajian dan pengungkapan laporan keuangan perusahaan sample, termasuk PSAK 13 mengenai properti investasi. Selanjutnya penulis menganalisis lebih lanjut mengenai pengakuan, pengukuran properti investasi baik dengan model biaya maupun model nilai wajar, pelepasan serta pengungkapan atas properti investasi. Selain itu, penulis juga melakukan analisi terhadap perusahaan yang mengubah kebijakan pengukuran properti investasi sehubungan dengan berlakunya PSAK 13 (revisi 2007). Setelah dilakukan analisis, maka diperoleh gambaran mengenai bagaimana penerapan IFRS mengenai investment property pada perusahaan sampel serta pengaruhnya terhadap penyajian laporan keuangan yang dapat diukur melalui opini auditor independen atas kewajaran laporan keuangan tiap perusahaan.

\section{Hasil dan Pembahasan}

AUTO, ASII dan UNTR memilih mengubah model pengukuran yang semula menggunakan model biaya, setelah revisi di tahun 2011 beralih menggunakan model nilai 
wajar dengan penyesuaian-penyesuaian yang juga diungkapkan sedangkan ketiga perusahaan lainnya yakni TURI, SMSM dan IMAS tetap dengan model biaya.

Pengungkapan properti investasi perusahaan terbagi menjadi dua bagian, yakni pengungkapan umum serta pengungkapan pada model nilai wajar atau pengungkapan pada model biaya. Masing-masing pengungkapan memiliki poin-poin tersendiri yang seluruhnya harus disajikan dalam laporan keuangan. Perusahaan sampel yang merupakan entitas dengan akuntabilitas publik diharuskan melakukan pengungkapan tersebut. dari data laporan keuangan, didapatakan bahwa masih ada perusahaan yang belum lengkap dalam hal pengungkapan atas properti investasi terutama pengungkapan atas penambahan, pengurangan maupun reklasifikasi terkait properti investasi tersebut. pengungkapan dan penyajian yang lengkap dapat digunakan untuk menilai apakah perusahaan tersebut telah menerapkan PSAK dengan tepat atau justru sebaliknya.

Hasil analisis atas laporan keuangan auditan didapatkan bahwa dalam enam periode laporan keuangan yang diteliti, opini yang mendominasi yakni opini wajar tanpa pengecualian dengan bahasa penjelasan (WTP dengan bahasa penjelas), jika dipresentasikan mencapat $64,58 \%$ dan sisanya adalah opini wajar tanpa pengecualian sebesar $35,42 \%$. Hal tersebut menandakan bahwa laporan keuangan perusahaan sampel untuk setiap periode telah disajikan sesuai dengan prinsip akuntansi yang berlaku umum di indonesia. Sehingga penerapan PSAK menentukan bagaimana penyajian dan pengungkapan unsur laporan keuangan tersebut dalam laporan keuangannya. Dan penyajian serta pengungkapan laporan keuangan berpengaruh dalam pemberian opini dari auditor independen. Berarti perusahaan sampel merupakan perusahaan yang telah menyajikan laporan keuangan sesuai dengan standar berlaku umum di Indonesia sehingga opini atas laporan keuangan yang mendominasi adalah opini wajar tanpa pengecualian.

\section{Kesimpulan}

1. AUTO, ASII dan UNTR memilih mengubah model pengukuran yang semula menggunakan model biaya, setelah revisi di tahun 2011 beralih menggunakan model nilai wajar dengan penyesuaian-penyesuaian yang juga diungkapkan sedangkan ketiga perusahaan lainnya yakni TURI, SMSM dan IMAS tetap dengan model biaya.

2. Kewajaran penyajian laporan keuangan dapat mencerminkan keandalan laporan keuangan yang disajikan oleh manajemen perusahaan. Tinggi rendahnya tingkat keandalan laporan keuangan yang idcerminkan dari opini auditor akan menentukan 
kegunaan laporan keuangan tersebut sebagai dasar atau bahan pertimbangan dalam membuat keputusan-keputusan ekonomi bagi para pengguna laporan keuangan.

3. Dalam penerapan PSAK 13 Revisi 2011 (adopsi IAS 40) didapatkan bahwa opini yang diperoleh perusahaan sampel adalah WTP dan WTP dengan bahasa penjelas. Opini yang diperoleh tersebut yang menandakan bahwa penyajian laporan keuangan perusahaan sampel pada umumnya telah mematuhi standar yang berlaku. Dari paparan tersebut dapat dinyatakan bahwa penerapan IFRS mengenai investment property berpengaruh terhadap penyajian laporan keuangan perusahaan subsektor otomotif yang terdaftar di BEI.

\section{Daftar Pustaka}

Abdul Kadir. 2012. Analisis Pengaruh Penerapan IFRS Mengenai Investment Property terhadap Pengakuan Laba Perusahaan (Studi Kasus pada PT Astra Internasional Tbk., PT Astra Otoparts Tbk., dan PT Astra Graphia Tbk. yang Terdaftar di BEI). Jurnal Spread. Vol 2(2): Hal 107-116.

Akuntan Indonesia. Edisi 16. 2009. Hal 16-26.

Dwi Martani, dkk. 2012. Akuntansi Keuangan Menengah Berbasis PSAK. Salemba Empat. Jakarta.

Greuning, Hennie Van. 2005. International Financial Standards: A Practical Guide. Salemba Empat. Jakarta.

Harahap, Sofyan S. 2007. Teori Akuntansi. Raja Grafindo. Jakarta.

Herman Hisar. 2012. Dampak Penerapan PSAK 13 Revisi 2011 pada Perusahaan Properti:

Studi Kasus pada PT TBI. Skripsi Program Sarjana Universitas Indonesia. Depok.

Ikatan Akuntansi Indonesia. 2011. Pernyataan Standar Akuntansi Keuangan. Salemba Empat. Jakarta.

KPMG Publication. IFRS Compared to Indonesian GAAP. 2010.

Moleong, J Lexy. 2007. Metode Penelitian Kualitatif. Rosda. Bandung.

Mulyadi. 2010. Auditing. Salemba Empat. Jakarta.

Nur Cahyonowati \& Dwi Ratmono. 2012. Adopsi IFRS dan Relevansi Nilai Informasi Akuntansi. Jurnal Akuntansi dan Keuangan. Vol 14(2): Hal 105-115. 
Analisis Pengaruh Penerapan IFRS mengenai Investment Property terhadap Penyajian Laporan Keuangan (Studi Kasus pada Perusahaan Sektor Otomotif yang Terdaftar di BEI)

Purba, Marisi P. 2010. IFRS Konvergensi dan Kendala Aplikasinya di Indonesia. Graha Ilmu. Yogyakarta.

Sartika. 2012. Analisis Implementasi PSAK 13: Properti Investasi Studi Kasus pada Perusahaan Non-Keuangan yang Terdaftar di BEI Tahun 2008-2009. Skripsi Program Sarjana Universitas Indonesia. Depok.

Tuanakotta, Theodorus M. 2000. Teori Akuntansi, Buku 1. Lembaga Penerbitan FE-UI. Jakarta.

Weygand, Jerry J. Keiso, Paul D, Donald E, dan Kimmel. 2008. Principal Accounting. Salemba Empat. Jakarta. 